УДК 159.9-043.61:796.412.2

DOI https://doi.org/10.32689/maup.psych.2021.3.7

\title{
Ангеліна КАЙЗЕРОВА
}

аспірантка кафедри психології, Інститут підготовки кадрів Державної служби зайнятості України, вул. Нововокзальна, 17, м. Київ, Україна, 03038

ORCID: 0000-0003-4690-5406

\section{Anhelina KAIZEROVA}

Postgraduate Student at the Department of Psychology, Ukrainian State Employment Service Training Institute, 17 Novovokzalna str., Kyiv, Ukraine, 03038

ORCID: 0000-0003-4690-5406

\section{ПСИХОЛОГІЧНІ БАР' ЄРИ ТРЕНУВАЛЬНОЇ ТА ЗМАГАЛЬНӦ̈ ДІЯЛЬНОСТІ СПОРТСМЕНІВ 3 ХУДОЖНЬОЇ ГІМНАСТИКИ PSYCHOLOGICAL BARRIERS TRAINING AND COMPETITIVE ACTIVITIES ATHLETES IN ARTISTIC ACTIVITY}

Тренувальна діяльність спортсменів з художньої гімнастики передбачає, окрім фізичної, технічної, тактичної та психологічної підготовки, розвиток психологічної готовності та формування психологічних компетентностей і навичок долати психологічні бар'єри у тренувальній та змагальній діяльності. У статті проаналізовано вирішення проблеми психологічних бар'єрів у зв'язку з актуальністю пошуків шляхів підвищення ефективності спортивної тренувальної діяльності особистості.

У контексті проблеми дослідження визначено, щзо питання психологічних бар'єрів охоплює такі наукові проблеми, як: теоретико-історична ситуація вивчення психологічних бар'єрів у науковій літературі; суб 'єктивне сприйняття психологічних бар 'єрів; психологічні бар'єри як ресурс мотивації особистісного розвитку.

Функиіями психологічних бар 'єрів визначено: 1) адаптивну; 2) регулятивну, щуо слугують мотиваторами активності особистості. У психології спорту бар 'єри (трудноші, перешкоди) характеризуються через дію зовнішніх факторів - предметних (біг з перешкодами), кліматичних (зустрічний вітер, вологість повітря); та впливу сочіально-психологічних чинників - мотивація психомоторної активності в тренувальній діяльності, особистісна психологічна готовність до тренування та участі у змаганнях, володіння прийомами самоорганізації/самомобілізації та стратегіями психоемоційної саморегуляиії та ін.

Мета статті полягає у теоретичному вивченні психологічних бар'єрів, труднощів у тренувальній та змагальній діяльності спортсменів із художньої гімнастики, аналізі чинників і механізмів їх виникнення.

Висновки. Визначено, що поняття «психологічний бар'єр» трактується як психічний стан особистості, шуо перешкоджає виконанню тих чи інших дій та виявляється в пасивності, апатії, опорі суб 'єкта.

3'ясовано, що виникнення психологічних бар'єрів у спортсменів зумовлюється: а) дією об'єктивних та суб'єктивних факторів; б) ступенем психологічної готовності до тренувальної та змагальної діяльності; в) особистісними якостями.

Психологічні бар 'єри у тренувальній та змагальній діяльності спортсменів з художсньӧ гімнастики виникають $і$ формуються як внутрішній опір чи захисні реакиії, в основі яких лежить механізм виникнення та утворення умовно-рефлекторних зв'язків психоемочійних реакцій у передбаченні дії суб'єктивних чи об'єктивних подразників (страх втримати предмет, оцінка суддів, реакція тренера, думка глядачів та ін.), які є значущиими для гімнастки.

Ключові слова: психологічний бар 'єр, функції і механізми психологічних бар'єрів, психоемоиійні стани.

The training activities of athletes in rhythmic gymnastics include, in addition to physical, technical, tactical and psychological training, the development of psychological readiness and the formation of psychological competencies and skills to overcome psychological barriers in training and competition. The article analyzes the solution to the problem of psychological barriers in connection with the urgency of finding ways to improve the effectiveness of sports training activities of the individual.

In the context of the identified research problem, it is determined that the issue of psychological barriers covers such scientific problems as: theoretical and historical situation of studying psychological barriers in the scientific literature; subjective perception of psychological barriers; psychological barriers as a resource to motivate personal development.

The functions of psychological barriers are: 1) adaptive; 2) regulatory, serving as motivators of personal activity. In the psychology of sports barriers (difficulties, obstacles) are characterized by the action of external factors - subject (obstacle course) climatic (headwind, humidity); and the influence of socio-psychological factors motivation of psychomotor activity in training activities, personal psychological readiness to train and participate in competitions, mastery of self-organization/self-mobilization techniques and strategies of psycho-emotional selfregulation, etc. 
The purpose of the article is to theoretically study psychological barriers, difficulties in training and competitive activities of athletes in rhythmic gymnastics, analysis of factors and mechanisms of their occurrence.

Conclusions. It is determined that the concept of "psychological barrier" is interpreted as a mental state of the individual that prevents the performance of certain actions and is manifested in passivity, apathy, resistance of the subject.

It was found that the emergence of psychological barriers of athletes is due to: a) the action of objective and subjective factors; b) the degree of psychological readiness for training and competitive activities; c) personal qualities.

Psychological barriers in the training and competitive activities of athletes in rhythmic gymnastics arise and are formed as internal supports or protective reactions, which are based on the mechanism of occurrence and formation of conditioned-reflex connections of psycho-emotional reactions in predicting the action of subjective or objective stimuli (fear of holding the subject, the judges'assessment, the coach's reaction, the audience's opinion, etc.), which are important for the gymnast.

Key words: psychological barrier, functions and mechanisms of psychological barriers, psycho-emotional states.

Актуальність дослідження. Протягом останніх років інтенсивно розвиваються такі напрями гімнастики, як: атлетична, оздоровча, ритмічна, спортивна, художня. Щороку змагальна програма у індивідуальних та групових вправах із художньої гімнастики стає більш видовищною: ускладнюється композиція та виконання елементів. Окрему увагу науковцями (Д. Абдулвахід, Н. Височіна, Л. Карпенко, І. Полілуєва, Г. Топол) приділено командній підготовці спортсменів: технічним особливостям виконання групових вправ, що потребують точності виконання рухів з однаковою амплітудою, швидкістю, силою, та визначаються узгодженістю, чіткістю виконання технічних елементів.

Фахівці (Н. Андреєва, В. Адашевський, В. Болобан, С. Єрмаков, Я. Коваленко, T. Нестерова, Р. Терехина, I. Терещенко, О. Худолій, О. Шинкарук та ін.) відзначають, що конкурентоздатність на міжнародній спортивній арені потребує комплексного підходу до підготовки спортсменів: знання про структуру змагальної діяльності в художній гімнастиці, підготовленість спортсменів в індивідуальних та групових програмах $з$ урахуванням сенсомоторної координації та можливостей гімнасток, біомеханічних особливостей взаємодії спортсменок з предметами.

Художня гімнастика як складно-координований вид спорту за сучасних умов розвитку ставить перед тренерами, спортсменами завдання не лише підвищення рівня підготовленості гімнасток (тактичної, методичної, артистичної підготовленості й поінформованості), а потребує психологічних знань 3 вирішення комунікативних питань, самовладання, особистісної умотивованості, а також формування навичок долати психологічні бар'єри.

Аналіз останніх досліджень і публікацій. Проблему наукових досліджень, спрямованих на вивчення психологічних труднощів, представлено у роботах К. Платонова, О. Леонтьєва, Б. Ломова, А. Массанова,
В. Пономаренко, С. Рубінштейна, В. Шадрікова, К. Юнга та ін.

Найчастіше проблематика психологічних бар'єрів трапляється у дослідженнях життєдіяльності фахівця в екстремальних умовах (Ф. Василюк, Л. Срмолаєва, М. Левітов, Г. Ложкін, О. Недвига, В. Осьодло, О. Прохоров, О. Хміляр та ін.), що спрямовані на вивчення психоемоційної сфери, психічних станів, стресостійкості особистості.

У зв'язку з інтенсивністю освітніх інноваційних процесів у вітчизняній психології питання психологічних бар'єрів розглядається у аспекті творчої професійної діяльності педагогічних працівників (В. Бессоненко, А. Гірняк, Р. Грановська, Л. Підлісна, М. Савчин, В. Слободчиков, В. Семиченко, А. Фурман, Т. Щербан та ін.).

Мета статті полягає у теоретичному вивченні психологічних бар'єрів, труднощів у тренувальній та змагальній діяльності спортсменів із художньої гімнастики, аналізі чинників і механізмів їх виникнення.

Виклад основного матеріалу. Спортивна діяльність характеризується специфічною руховою особливістю, структурою та змістом спортивних вправ. Залежно від видів спортивних дій перед спортсменами ставляться завдання та відпрацьовуються способи досягнення мети - перемога в змаганнях.

Спортивна змагальна діяльність є однією із форм прагнення людини до самоздійснення через самовдосконалення та досягнення спортивних результатів, що стає одним із формуючих компонентів гармонійного розвитку особистості. Змагальний результат зумовлює особливості побудови програми навчальнотренувального процесу, а також визначає зміст підготовки спортсмена до змагань (мета, завдання досягнення результату спортсмена в боротьбі зі спортивним суперником).

Специфіка тренувальної діяльності спортсменів 3 художньої гімнастики передбачає, окрім фізичної, технічної, тактичної та психологічної підготовки, розвиток психологічної 
готовності та формування психологічних компетентностей і навичок долати психологічні бар'єри у тренувальній та змагальній діяльності. Досягнення мети (виконання тактичних завдань, відпрацювання програмної композиції та ін.) потребує від спортсмена затрат вольових і фізичних зусиль, умінь визначати причину появи внутрішніх перешкод, а тому стратегіï самовладання та саморегуляції можуть стати одним із ресурсів у найближчій перспективі - досягнення спортивних результатів, а у дальній - розвиток особистості.

Традиційно у психології поняття «психологічний бар'єр» трактується як внутрішня перешкода, що заважає людині виконувати деяку дію $[4 ; 6]$.

С. Головіним, А. Петровським, М. Ярошевським [2, с. 46; 9] «психологічний бар'єр» визначається як психічний стан, який виявляється в неадекватній пасивності суб'єкта, що перешкоджає виконанню ним тих чи інших дій.

A. Массанов поняття «психологічний бар'єр» трактує як «...складний психічний стан, що містить такі структурні компоненти, як: 1) переживання, що пов'язані з мотивацією до досягнення мети; 2) переживання, що пов'язані 3 раціональною й ірраціональною оцінкою умов і наслідків досягнення мети; 3) емоційні реакції на ситуацію досягнення мети; 4) функціональний стан вольових можливостей у ситуації досягнення мети» [5].

Таким чином, психологічний бар'єр розуміється як психоемоційний стан особистості, що перешкоджає здійсненню дії.

Теоретичний аналіз літератури з проблеми вивчення показав, що після появи мотиву до виконання певної дії може формуватися психологічний механізм бар'єра:

1) оцінка ситуації, власних можливостей щодо виконання дії на когнітивному та емоційно-оцінному рівнях;

2) психоемоційна реакція як оцінка попереднього етапу дії на передбачливий неприйнятний результат;

3) фіксація/усвідомлення психоемоційного стану для обрання подальшої стратегії діяльності.

Отже, в утворенні бар'єра беруть участь такі психічні регулятори поведінки, як: мотиваційні, когнітивні, емоційно-оцінні, поведінкові й вольові процеси індивіда. «Тільки несприятливої когнітивної або емоційної оцінки успішності майбутньої дії не досить для формування психологічного бар'єра. Потрібно, щоб мотивація знизилася й вольові зусилля були недостатніми для здійснення дії» [5]. Це своєю чер- гою формує функції психологічних бар'єрів: 1) адаптивну; 2) регулятивну, та слугує мотиваторами активності особистості.

3 огляду на вищезазначене науковцями виділено типи психологічних бар'єрів: когнітивні, емоційно-оцінні, поведінково-мотиваційні, вольові. Тип бар'єра визначається, грунтуючись на внутрішньоособистісних регуляторах та мотивах, що зумовлюються емоційно-вольовою сферою людини.

Індивідуально-психологічними чинниками, що впливають на динаміку психологічних бар'єрів особистості, є іiї індивідуальнопсихологічні особливості (особистісні якості, риси характеру, воля, емоційна стійкість, критичне мислення, визначеність і сила мотивів), що можуть регулювати й підвищувати бар'єро-/стресостійкість.

Причиною виникнення психологічного бар'єру є очікування особистістю негативного результату/оцінки значущої людини виконуваної/виконаної дії/процесу. За вивченням А. Массанова [4], родовими поняттями, що охоплюють психологічні бар'єри, є: «...психічний стан, особистість, намір, мотив, емоції, раціональні оцінки, вольові зусилля, передбачення, дії» [4, с. 16]. Причому поняття «психологічний бар'єр» дослідниками вживається у разі пошуку причин виникнення негативних реакцій, емоцій людини, формування установок, цінностей, комунікацій, прийняття рішень та ін.

Виникнення психологічних бар'єрів спортсменів зумовлюється: а) дією об'єктивних та суб'єктивних факторів; б) ступенем психологічної готовності до тренувальної та змагальної діяльності; в) особистісними якостями.

У психології спорту бар'єри (труднощі, перешкоди) характеризуються через дію зовнішніх факторів - предметних (наприклад, біг 3 перешкодами) кліматичних (зустрічний вітер, вологість повітря); та вплив соціальнопсихологічних чинників - мотивацію психомоторної активності в тренувальній діяльності, особистісну психологічну готовність до тренування та участі у змаганнях, володіння прийомами самоорганізації/самомобілізації та стратегіями психоемоційної саморегуляції та ін. Неготовність до дії зовнішніх та внутрішніх факторів на психоемоційну сферу може викликати негативні емоційні стани спортсмена.

Для спортсмена бар'єри виступають та сприймаються як опір/реакція фізичних сил організму та як джерело «загрозливої інформації». У психології спорту бар'єри/труднощі/перешкоди розглядають в об'єктивному і суб'єктивному аспектах. 
Психічні стани спортсменів 3 художньої гімнастики у тренувальній і змагальній діяльності

\begin{tabular}{|c|c|c|c|}
\hline $\begin{array}{l}\mathbf{N o} \\
\text { 3/II }\end{array}$ & Психічний стан & Характеристика психічного стану & Причини виникнення \\
\hline 1. & $\begin{array}{l}\text { Очікування фізичного } \\
\text { болю чи отримання } \\
\text { травми, больовий синдром } \\
\end{array}$ & $\begin{array}{l}\text { страх болю, нестача енергії, бажання } \\
\text { все кинути, жалість до себе }\end{array}$ & \multirow{2}{*}{$\begin{array}{l}\text { досвід переживання } \\
\text { негативних результатів, } \\
\text { фізична та психоемоційна } \\
\text { втома }\end{array}$} \\
\hline 2. & $\begin{array}{l}\text { Невпевненість у своїх } \\
\text { силах, сумніви, острах } \\
\text { критики }\end{array}$ & $\begin{array}{l}\text { відсутність сталого інтересу та } \\
\text { мотивації до своєї діяльності і } \\
\text { тренувального процесу }\end{array}$ & \\
\hline 3. & $\begin{array}{l}\text { Страх поразки, зайве } \\
\text { хвилювання }\end{array}$ & $\begin{array}{l}\text { знижений тонус м'язів, емоційна } \\
\text { закритість, відстороненість від } \\
\text { ситуації }\end{array}$ & $\begin{array}{l}\text { відсутність критичного } \\
\text { мислення в оцінці ситуації, } \\
\text { суперника, функціонування } \\
\text { організму; стратегій } \\
\text { особистісної саморегуляції, } \\
\text { концентрації, мотивації }\end{array}$ \\
\hline 4. & Психофізична паніка & $\begin{array}{l}\text { емоційна та фізична некерованість, } \\
\text { неможливість вплинути на ситуацію }\end{array}$ & $\begin{array}{l}\text { передчасна думка про } \\
\text { результат, змагальна напруга }\end{array}$ \\
\hline 5. & Психічна саморегуляція & $\begin{array}{l}\text { Мобілізація вольових властивостей, } \\
\text { психоемоційний контроль, } \\
\text { самопереконання }\end{array}$ & $\begin{array}{l}\text { мотиви самоствердження, } \\
\text { досягнення спортивного } \\
\text { результату }\end{array}$ \\
\hline 6. & Психологічна втома & $\begin{array}{l}\text { відсутність сталого інтересу та } \\
\text { мотивації до своєї навчальної } \\
\text { діяльності і тренувального процесу }\end{array}$ & $\begin{array}{l}\text { монотонні/однотипні за } \\
\text { змістом і навантаженням } \\
\text { тренування }\end{array}$ \\
\hline 7. & Передстартова апатія & $\begin{array}{l}\text { емоційна і фізична виснаженість, } \\
\text { низький тонус м’язів, емоційна } \\
\text { байдужість до ситуації }\end{array}$ & $\begin{array}{l}\text { перевитрата фізичних і } \\
\text { емоційних ресурсів, мотивація } \\
\text { уникнення невдачі }\end{array}$ \\
\hline 8. & Передстартова лихоманка & $\begin{array}{l}\text { особистісна і реактивна тривожність, } \\
\text { напружений м'язовий тонус, хаотичні } \\
\text { рухи, бажання вирішити ситуацію }\end{array}$ & $\begin{array}{l}\text { психофізичне збудження, } \\
\text { висока мотивація досягти } \\
\text { найкращого результату }\end{array}$ \\
\hline 9. & Самовладання & $\begin{array}{l}\text { рішучість, впевненість, контроль } \\
\text { м’язового тонусу, включеність у } \\
\text { ситуацію }\end{array}$ & $\begin{array}{l}\text { психоемоційна та фізична } \\
\text { підготовленість організму, } \\
\text { висока мотивація досягнення } \\
\text { результату }\end{array}$ \\
\hline
\end{tabular}

Психологічні бар'єри у тренувальній та змагальній діяльності спортсменів з художньої гімнастики виникають i формуються як внутрішній опор чи захисні реакції, в основі яких лежить механізм виникнення та утворення умовно-рефлекторних зв'язків психоемоційних реакцій у передбаченні дії суб'єктивних чи об'єктивних подразників (страх не втримати предмет, оцінка суддів, реакція тренера, думка глядачів та ін.), які є значущими для гімнастки.

Аналіз психічних станів гімнасток демонструє, що психологічні бар'єри можуть бути свідченням переживаннь: «боротьба» - мобілізація сил і подолання бар'єра; «відстрочка»відкладання на час подолання бар'єра для того, щоб ще раз оцінити ситуацію або провести додаткову підготовку; «відмова» - переоцінка ситуації й зміна мети або знаходження приводу для відмови від такої дії; «виснаженість» - стрес, фрустрація, внутрішній конфлікт, внутрішня криза [5].

Для попередження та подолання психологічних бар'єрів застосовується механізм волі - спрямована концентрація психічних і фізичних властивостей та ресурсів організму 3 метою подолання перешкоди. Профілактика появи психологічних бар'єрів у взаємодії зі спортсменами з художньої гімнастики має також дискусію: бар'єри особистості виконують як негативну, так і позитивну функції: аналіз спортивної діяльності, мотивація розвитку координаційно-функціональних умінь і навичок; формування компетентності у емоційному владанні з очікуванням бар'єра за рахунок мобілізації власних можливостей та ресурсів. Тобто виникає запитання: у яких випадках доцільно попереджати виникнення бар'єра як деструктивної дії та деформуючого впливу на особистість, а коли варто сприймати психологічний бар'єр як фактор мотивації до удосконалення. Тобто, поділяючи думку багатьох авторів (таких як Г. Балл, В. Костюкевич, А. Массанов, О. Матюшкін, Т. Нестерова, I. Полілуєва, Я. Пономарьов та ін.), відзначимо дуальну роль психологічних бар'єрів.

Висновки. У змістовно-функціональному аспекті психологічні бар'єри розглядаються як труднощі, опір на шляху досягнення мети, 
а також виступають як мотиватори та ресурси для виконання поставлених завдань.

Особистісна стратегія переживання психологічного бар'єра здійснюється через функціональний механізм: а) мобілізація психоемоційних і фізичних ресурсів; б) аналіз та оцінка ситуації з перспективним планом дій; в) припрацювання психічних станів (емоційного виснаження, фрустрації, апатії...); г) переоцінка мети і завдання подальшої дії.

Перспективою подальших наукових розвідок стане вивчення соціально-психологічних чинників тренувальної діяльності спортсменів.

\section{Література:}

1. Белокопытова Ж.А., Дячук А.М. Факторы, определяющие эффективность начальной подготовки в художественной гимнастике. Физическое воспитание студентов. 2010. № 2. С. 24-28.

2. Головин С.Ю. Словарь практического психолога. Минск : Харвест, 2001. 592 c. URL: https:// elenamatichina.ucoz.net/literatura/slovar_prakticheskogo_psikhologa.pdf.

3. Костюкевич В.М. Теорія і методика спортивної підготовки (на прикладі командних ігрових видів спорту) : навчальний посібник. Вінниця : Планер, 2014, 616 с.

4. Массанов А.В. Психологічні бар'єри в професійному самовизначенні особистості : дис. ... докт. психол. наук : 19.00.07. Одеса, 2010. 409 с.

5. Массанов А.В. Психологічні бар'єри в діяльності людини. URL: https://scienceandeducation.pdpu. edu.ua/doc/2009/4_2009/5.pdf.pdf.

6. Немов Р.С. Психология : учебник для студентов высших педагогических учебных заведений. Москва : Гуманит. изд. центр ВЛАДОС, 2003. 688 с.

7. Нестерова Т.В. Структура многолетней подготовки спортсменок на уровне достижений в художественной гимнастике. Современный олимпийский спорт и спорт для всех. 2007. С. 182-185.

8. Полілуєва І.В. Особливості емоційно-вольової регуляції спортивно-художньої діяльності у підлітковому віці : дис. ... канд. психол. наук : 19.00.07. Харків, 2018. 235 с.

9. Петровский А.В., Ярошевский М.Г. Психологический словарь. Москва : Политиздат, 1990. 449 с.

10. Сосина В.Ю. Хореография в гимнастике. Киев : Олимпийская литература, 2009. 146 с.

11. Топол Г.А. Комплексна оцінка підготовленості кваліфікованих спортсменок у художній гімнастиці : дис. ... канд. наук з фізичного виховання і спорту : 24.00.01. Київ, 2017. 217 с.

12. Kozina Z., Chaika O., Safronov D., Prokopenko I., Kozin S., Shkrebtii Y., Trubchaninov M., Falyova O. Biomechanical Running Indicators and Neurodynamic Functions of an Elite Athlete with Visual Impairment in a Track and Field Sprint. International Journal of Applied Exercise Physiology. 2019. Vol. 8. P. 10-25.

\section{References:}

1. Belokopytova, Zh.A., Djachuk, A.M. (2010). Faktory, opredeljajushhie jeffektivnost' nachal'noj podgotovki v hudozhestvennoj gimnastike [Factors that determine the effectiveness of initial training in rhythmic gymnastics]. Fizicheskoe vospitanie studentov - Physical education of students. 2. S. 24-28 [in Russian].

2. Golovin, S.Ju. (2001). Slovar' prakticheskogo psihologa [Practical Psychologist's Dictionary]. Minsk : Harvest.

3. Kostjukevich, V.M. (2014). Teorija i metodika sportivnoyi pidgotovki (na prikladi komandnih igrovih vidiv sportu) [Theory and methods of sports training (on the example of team games)]. Vinnicja : Planer [in Ukrainian].

4. Massanov, A.V. (2010). Psihologichni bar'eri v profesijnomu samoviznachenni osobistosti [Psychological barriers in professional self-determination]. Doctor's thesis. Odesa [in Ukrainian].

5. Massanov, A.V. Psihologichni bar'eri v dijal'nosti ljudini [Psychological barriers in human activity]. Retrieved from: https://scienceandeducation.pdpu.edu.ua/doc/2009/4_2009/5.pdf.pdf [in Ukrainian].

6. Nemov, R.S. (2003). Psihologija [Psychology]. Moskva: Gumanit. izd. centr VLADOS [in Russian].

7. Nesterova, T.V. (2007). Struktura mnogoletnej podgotovki sportsmenok na urovne dostizhenij $\mathrm{v}$ hudozhestvennoj gimnastike [The structure of long-term training of female athletes at the level of achievements in rhythmic gymnastics]. Sovremennyj olimpijskij sport i sport dlja vseh-Modern Olympic sports and sports for all, 182-185 [in Ukrainian].

8. Polilueva, I.V. (2018). Osoblivosti emocijno-vol'ovoyi reguljaciyi sportivno-hudozhn'oyi dijal'nosti u pidlitkovomu vici [Features of emotional and volitional regulation of sports and artistic activities in adolescence]. Candidate's thesis. Harkiv [in Ukrainian].

9. Petrovskij, A.V., Jaroshevskij, M.G. (1990). Psihologicheskij slovar' [Psychological Dictionary]. Moscow: Politizdat [in Russian].

10. Sosina, V.Ju. (2009). Horeografija v gimnastike [Choreography in gymnastics]. Kyiv: Olimpijskaja literatura [in Ukrainian].

11. Topol, G.A. (2017). Kompleksna ocinka pidgotovlenosti kvalifikovanih sportsmenok u hudozhnij gimnastici [Comprehensive assessment of the training of qualified athletes in rhythmic gymnastics]. Candidate's thesis. Kyiv [in Ukrainian].

12. Kozina, Z., Chaika, O., Safronov, D., Prokopenko, I., Kozin, S., Shkrebtii, Y., Trubchaninov, M., Falyova, O. (2019). Biomechanical Running Indicators and Neurodynamic Functions of an Elite Athlete with Visual Impairment in a Track and Field Sprint. International Journal of Applied Exercise Physiology. 8: 10-25. 